\title{
Geobotanical Characterization of a Geothermal System Using Hyperspectral Imagery: Long Valley Caldera, CA, USA
}

\author{
B. A. Martini, S. A. Cochran, D. C. Potts, \\ E. A. Silver, W. L. Pickles, M. R. Carter,
}

R. E. Priest, B. M. Wayne, and W. T. White III

\section{December 1998}

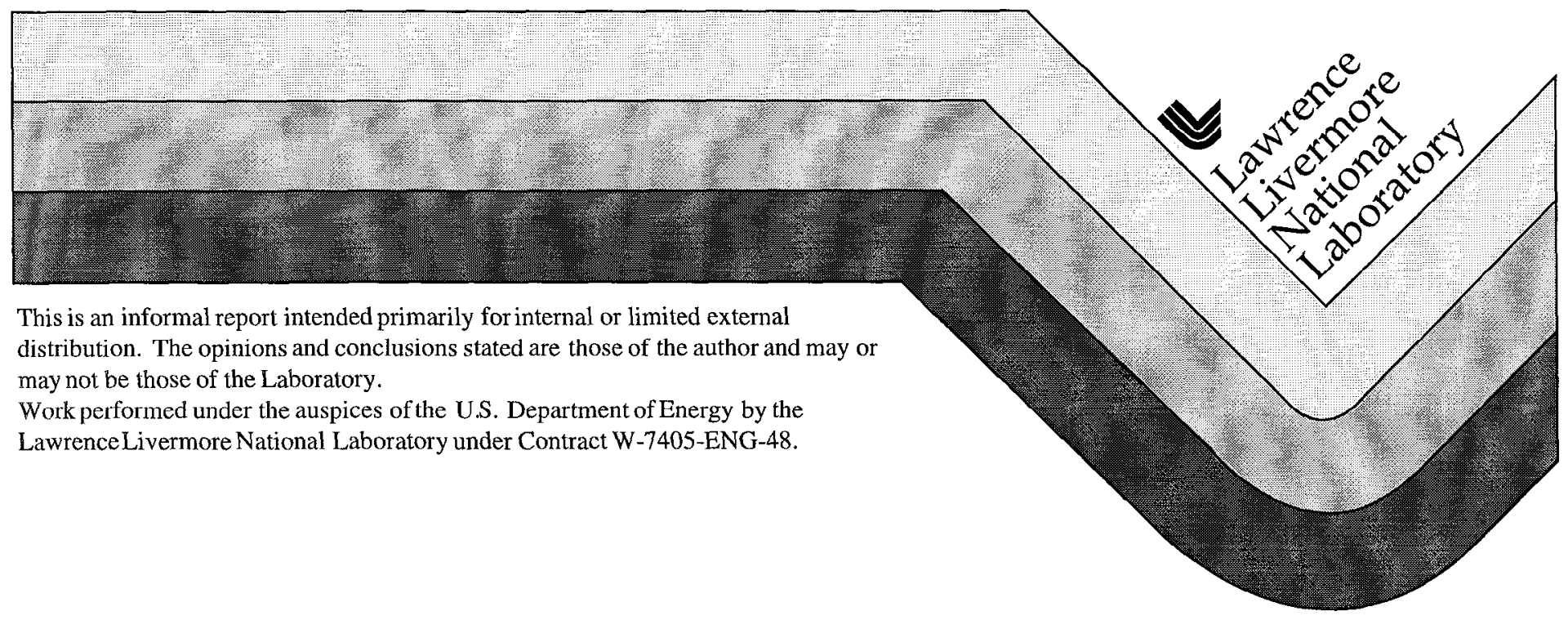




\section{DISCLAIMER}

This document was prepared as an account of work sponsored by an agency of the United States Government. Neither the United States Government nor the University of California nor any of their employees, makes any warranty, express or implied, or assumes any legal liability or responsibility for the accuracy, completeness, or usefulness of any information, apparatus, product, or process disclosed, or represents that its use would not infringe privately owned rights. Reference herein to any specific commercial product, process, or service by trade name, trademark, manufacturer, or otherwise, does not necessarily constilule or imply its endorsement, recommendation, or favoring by the Uniled States Government or the University of California. The views and opinions of authors expressed herein do not necessarily state or reflect those of the United States Government or the University of California, and shall not be used for advertising or product endorsement purposes.

This report has been reproduced directly from the best available copy.

Available to DOE and DOE contractors from the

Office of Scientific and Technical Information

P.O. Box 62, Oak Ridge, TN 37831

Prices available from (423) 576-8401

Available to the public from the

National Technical Information Service

U.S. Department of Commerce

5285 Port Royal Rd.,

Springfield, VA 22161 


\title{
GEOBOTANICALCHARACTERIZATIONOFAGEOTHERMALSYSTEM USINGHYPERSPECTRALIMAGERY:LONGVALLEYCALDERA,CA,USA
}

\author{
B. A. Martini \\ S. A. Cochran \\ D. C. Potts \\ E. A. Silver \\ University of California \\ Santa Cruz, CA 95064 \\ W.L. Pickles \\ M. R. Carter \\ R. E. Priest \\ B. M. Wayne \\ W. T. White III \\ Lawrence Livcrmore National Laboratory \\ University of California \\ Livermore, CA, USA
}

\begin{abstract}
We have analyzed hyperspectral Airborne Visible-Infrared Imaging System (AVIRIS) imagery taken in September of 1992 in Long Valley Caldera, CA, a geothermally active region expressed surficially by hot springs and fumaroles. Geological and vegetation mapping are attempted through spectral classification of imagery. Particular hot spring areas in the caldera are targeted for analysis. The data is analyzed for unique geobotanical patterns in the vicinity of hot springs as well as gross identification of dominant plant and mineral species. Spectra used for the classifications come from a vegetation spectral library created for plant species found to be associated with geothermal processes. This library takes into account the seasonality of vegetation by including spectra for species on a monthly basis. Geological spectra are taken from JPL and USGS mineral libraries. Preliminary classifications of hot spring areas indicate some success in mineral identification and less successful vegetation species identification. The small spatial extent of individual plants demands either sub-pixel analysis or increased spatial resolution of imagery. Future work will also include preliminary analysis of a hyperspectral thermal imagery dataset and a multitemporal air photo dataset. The combination of these remotely sensed datasets for Long Valley will yield a valuable product for geothermal exploration efforts in other regions.
\end{abstract}

\subsection{INTRODUCTION}

Active geothermal regions can be characterized by a specific suite of minerals and vegetation. Processes occurring in such environments facilitate the unique interaction between the biological and geological world resulting in predictable patterns. In general, geothermal processes include fumarolic activity, increased geothermal gradients, and discharge of hot water both at the surface and at depth. The interaction of these 
geothermal processes with the in situ geology results in alteration of the rock to characteristic hydrothermal mineral assemblages. The further interaction of both the ongoing and sometimes cyclic geothermal processes and the mineral assemblages with the vegetation results in patterns dictated by a plant's growth threshold. These thresholds are constrained partly by temperature and $\mathrm{pH}$. One way to study these patterns is through the use of hyperspectral imagery such as that provided by the AVIRIS instrument. There has been great success in using hyperspectral data to characterize mineral provinces

(F.A.Kruse, 1988, 1990, 1993; J.W. Boardman and J.F. Huntington, 1996). Less work has been done with vegetation due to the complex nature of delineating different species of plants which are chemically very similar to one another. However, airborne hyperspectral data has also been successfully used to characterize vegetation communities and condition (R. Merton, 1998; S.M. de Jong, 1996, R.N. Clark et al, 1995). We attempt a geobotanical approach aimed at analysis of hyperspectral imagery of a geothermal region in Long Valley Caldera, California. A similar study in Yellowstone has yielded very good results (R.F. Kokaly et al, 1998). In addition to AVIRIS imagery of the region, we also consider the value of other remote sensing techniques including thermal hyperspectral imagery and photogrammetry. These datasets provide a valuable tool for applied geothermal exploration and exploitation efforts.

\subsection{LONG VALLEY CALDERA}

Long Valley Caldera is a $0.73 \mathrm{Ma}$ caldera located in central-eastern California on the edges of the Sierra Nevada Mountains at a mean elevation of $2200 \mathrm{~m}$. Geology within the caldera itself is dominated by numerous basaltic, andesitic, and rhyolitic volcanic flows and tuffs, as well as sediments including sandstones, lacusterine deposits, and recent fluvial deposits. Lesser occurrences of travertine and siliceous sinter deposits are related to past and current hydrothermal activity. Present hydrothermal activity is located primarily on the south and southeast sides of the resurgent dome (Sorey, 1985). Activity is currently dominated by travertine deposition while sinter deposition seems to have been more important in the past (Lipshie, 1976). These hydrothermal deposits are localized predominately around the N-NW trending normal faults common to the caldera. Also indicative of hydrothermal activity are mineral assemblages formed from alteration of volcanics and sediments. Typical alteration products of hydrothermal processes include alkali sulfates and clays. This kind of alteration is observed in many of the deposits of the caldera.

Vegetation within the caldera and in the general vicinity of geothermal activity is represented by a few main species. Sagebrush (dominantly Artemisia Tridentata) covers much of the caldera floor. Though generally located in the vicinity of hot springs and fumaroles, sagebrush density decreases near the sites of geothermal activity. This population then grades into Rabbitbrush (Chrysothamnus nauseosus) as the center of 
activity is approached. Rabbitbrush often indicates a stressed environment; the stress in this situation being elevated ground temperatures, high $\mathrm{pH}$, and shallow subsurface hot water. Rabbitbrush eventually reaches its threshold for growth and gives way to various grasses, which in turn give way to hydrothermally altered rock and soil and finally to the geothermal feature itself.

In the case of hot springs and pools, various algae and bacteria must also be considered. These organisms exist at very specific temperature and $\mathrm{pH}$ thresholds, which can be used to characterize geothermal systems on a smaller scale.

\subsection{DATA ANALYSIS}

Two sources of data are utilized in this study: field spectroscopy and hyperspectral AVIRIS imagery. Field spectroscopy of vegetation is done with a portable spectroradiometer. Spectra of all major types of vegetation in the caldera coincident with geothermal activity are collected and stored in a spectral vegetation library. One issue concerning spectroscopy of vegetation is the relative importance of seasonal variation on the organisms. In order to analyze the effects of season, spectra of vegetation populations in specific areas are being taken once a month. No contemporaneously acquired spectral library exists for the September 1992 data. Therefore, spectra used in the classification of AVIRIS imagery in our study are August, September, and October spectra from 1998 which surrounds the original month of flight in 1992. August and October spectra are used to account for possible climate differences experienced by the plants in 1992 and 1998. Mineral spectra are extracted from both USGS and JPL mineral libraries.

The spectral libraries are then used in analysis of hyperspectral AVIRIS imagery acquired on September 2, 1992. AVIRIS is a 224 band instrument which images from 400 $-2500 \mathrm{~nm}$ with a $10 \mathrm{~nm}$ sample interval. Spatial resolution is $20 \mathrm{~m}$. Analysis of this imagery includes ATREM calculated atmospheric corrections. Preliminary classifications of spatial subsets within an AVIRIS image are encouraging. Areas of particular interest include Whitmore Tubs, Whitmore Hot Springs, Hot Creek, Little Hot Creek, and the Alkali Flats region。 The classifications appear to be identifying clays in the vicinity of some of the hot springs. Previously mapped outcrops of travertine are also identified in the image analysis.

Delineation of vegetation type has proved more challenging. The small size of individual specimens of sagebrush and rabbitbrush has made it difficult to pick up the thresholded vegetation zonation observed around hot springs. Microbial mats and algae populations are also difficult to classify in AVIRIS imagery because of their small spatial extent. A few pixels in the Little Hot Creek region seem to contain Igappopulations of some kind, however the spectral signaturcs in this vicinity are dominantly hydrothernal minerals and other vegetation. Smaller and less spatially extensive organisms can fall victim to the mixed pixel problem, which we plan to address in the future with pixel unmixingstrategies. 


\subsection{FUTURE WORK}

Further analysis of the AVIRIS images will be completed with an eye to improving initial classification efforts on the basis of both the mineralization and the vegetation. Solving the problem of the small size and spatial extent of the vegetation indicative of hydrothermal activity will be attempted through partial unmixing of pixels as outlined in J.W. Boardman, 1995. Ultimately, the quality of the classified image produced is limited by the greater age of this dataset. More recent AVIRIS imagery of this region would be ideal. Of course another solution to the problem of small features is to increase the resolution of the imagery. Ideally, higher resolution imagery in the range of 1-5 m would allow classifications with a lower amount of pixel unmixing required. Obtaining such a dataset of the caldera is of primary concern for future studies.

Final classified images, post-rectification, will be ground truthed for accuracy of mineral and plant species identification. Future work will also include analysis of imagery acquired from a thermal hypersper inger operated by Lawence Livermore National Laboratory (LLNL). This isa 792 band instrument, which images from $750-1250 \mathrm{~cm}^{-1}$. Images of Long $\vee$ alley were acquired by this instrument in July of 1998. Issues addressed in the analysis of the imagery will include surface temperature extraction, mineral identification, and whether acquisition of hyperspectral thermal data is a valuable addition to lower wavelength hyperspectral acquisitions such as AVIRIS.

Photogrammetry studies are also planned. The dynamic nature of hot springs and the relatively short response time of the vegetation to these changes lends itself to a study of multi-temporal air photo datasets. Documentation of both spatial changes in vegetation populations and species change will be attempted. The integration of the datasets discussed in this study will be put into a GIS atmosphere, which will allow for comparisons with other geological and biological datasets such as heat flow and structure. A GIS dataset encompassing spectral, geological, and biological information is the optimal end product for geothermal companies to utilize for exploration and exploitation of a givenregion.

\subsection{CONCLUSION}

Spectral classifications of AVIRIS imagery yield valuable information about the geology and vegetation of a region. The dependence of vegetation on the environment created by the geology is of particular interest. An area characterized by geothermal processes is home to many unique geobotanical interactions that can be observed spectrally and mapped. Such maps can be combined with other data to provide a synoptic view of a geothermal region valuable to the geothermal industry. The approaches proposed in this study can then be used in other possibly economic geothermal regions around the world. 


\subsection{REFERENCES}

Boardman, J.W. and J.F. Huntington, 1996, Mineral Mapping with 1995 AVIRIS Data, Summaries of the Sixth Annual JPL Airborne Earth Science Workshop, JPL Publication 96-4, pp. 9-11

Boardman, J.W., F. A. Kruse, and R.O. Green, 1995, Mapping Target Signatures Via Partial Unmixing of AVIRIS Data, Summaries of the Fifth Annual JPL Airborne Earth Science Workshop, JPL Publication 95-1, pp. 23-26

Clark, R.N., T.V.V. King, C. Ager, and G.A. Swayze, 1995, Initial Vegetation Species and Senescence/Stress Indicator Mapping in the San Luis Valley, Colorado Using Imaging Spectrometer Data, Summaries of the Fifth Annual JPL Airborne Earth Science Workshop, JPL Publication 95-1, pp. 35-38

De Jong, S.M., 1996, Surveying Dead Trees and $\mathrm{CO}^{2}$-Induced Stressed Trees Using AVIRIS in the Long Valley Caldera, Summaries of the Sixth Annual JPL Airborne Earth Science Workshop, JPL Publication 96-4, pp. 67-74

Kokaly, R.F., R.N. Clark, and K.E. Livo, 1998, Mapping the Biology and Mineralogy of Yellowstone National Park Using Imaging Spectroscopy, Summaries of the Seventh Annual JPL Airborne Earth Science Workshop, JPL Publication 97-21, pp. 245-254

Kruse, F.A., 1988, Use of Airborne Imaging Spectrometer Data to Map Minerals Associated with Hydrothermally Altered Rocks in the Northern Grapevine Mountains, Nevada and California, Remote Sensing of Environment, v. 24, No. 1, pp. $31-51$

Kruse, F.A., K.S. Kierein-Young, J.W. Boardman, 1990, Mineral Mapping at Cuprite, Nevada with a 63 Channel Imaging Spectrometer, PhotogrammetricEngineering and Remote Sensing, v. 56, no. 1, pp. 83-92

Kruse, F.A., A.B. Lefkoff, J.B. Dietz, 1993, Expert System-Based Mineral Mapping in Northern Death Valley, California/Nevada using the Airborne Visible/Infrared Imaging Spectrometer (AVIRIS), Remote Sensing of Environment, v. 44, pp. 309 336

Lipshie, S.R., 1976, Geologic Guidebook to the Long Valley-Mono Craters Region, GSUCLA Field Guide 5, 184 pp, Geological Society of University of California, Los Angeles

Merton, R., 1998, Monitoring Community Hysteresis Using Spectral Shift Analysis and 
the Red-Edge Vegetation Stress Index, Summaries of the Seventh Annual JPL Airborne Earth Science Workshop, JPL Publication 97-21, pp. 275-285

Sorey, M.L., 1985, Evolution and Present State of the Hydrothermal System in Long Valley Caldera, Journal of Geophysical Research, v. 90, no. B13, pp. 11,21911,228 